\title{
POCHODZENIE, BUDOWA I FUNKCJONOWANIE UKRAIŃSKICH NAZW PODZESPOLÓW KOMPUTEROWYCH
}

\author{
PRZEMYSLAW JÓŹWIKIEWICZ \\ Uniwersytet Wrocławski, Wrocław — Polska \\ ПОХОДЖЕННЯ, ПОБУДОВА І ФУНКЦІОНУВАННЯ \\ УКРАЇНСЬКИХ НАЗВ КОМП‘ЮТЕРНИХ ПІДСИСТЕМ \\ ПШЕМИСЛАВ ЮЗЬВІКЕВИЧ \\ Вроцлавський університет, Вроцлав - Польща
}

АНОТАЦІЯ. У статті розглянуто питання походження, функціонування та будови українських назв найпопулярніших комп’ютерних термінів. Особливу увагу приділено генезі української комп“ютерної лексики, запозиченням та особливостям їх функціонування в сучасному мовленні українців.

\section{ORIGIN, STRUCTURE AND FUNCTIONING OF UKRAINIAN NAMES IN COMPUTER TERMINOLOGY}

\author{
PRZEMYSŁAW JÓŹWIKIEWICZ \\ University of Wrocław, Wrocław - Poland
}

\begin{abstract}
ABSRACT. The article focuses on the problems of origin, functioning and structure of Ukrainian names of computer terms. The main attention has been paid to the genesis of Ukrainian computer terms, borrowings and peculiarities of their functioning in modern speech of rhe Ukrainians.
\end{abstract}

$\mathrm{P}$ oszczególne leksemy czy struktury o większym stopniu złożoności należące do zasobów leksykalnych rzadziej pojawiających się w przestrzeni publicznej mogą u przeciętnego użytkownika języka wywołać uczucie konsternacji, wywołane niezrozumieniem treści zawartych w odczytywanych komunikatach. Zjawisko to dotyczy w szczególności terminologii, którą posługują się wąskie grupy zawodowe, społeczne, pasjonackie, w tym także słownictwa informatycznego. Jednakże istotna różnica pomiędzy obecnością w obrębie języka ogólnego terminologii lotniczej, więziennej czy filatelistycznej, a informatycznej polega na tym, iż z coraz większą częstotliwością styka się z nią każdy z nas. Kontakt ten w przeciągu ostatniej dekady znacząco przybrał na sile, a przyczyn zjawiska upatrywać należy w coraz szerszym dostępie do nowoczesnych technologii, informatyzacji społeczeństw, wszechobecnych produktach przemysłu IT.

Ukraińska terminologia informatyczna, choć obecna w ukraińskiej przestrzeni językowej, jest tu wciąż zjawiskiem nowym i na co dzień spotykanym dość sporadycznie. Przyczyn takiej sytuacji jest co najmniej kilka. Gdyby jednak chcieć wymienić jedynie najważniejsze $\mathrm{z}$ nich, to należałoby wspomnieć przede wszystkim o: 1) dość ograniczonym udziale języka ukraińskiego w procesie powstawania i funkcjonowania ukraińskiego przemysłu specjalizującego się w opracowywaniu i pro- 
dukcji maszyn liczących ${ }^{1}$, a co za tym idzie braku odpowiednich podstaw, które dziś stanowiłyby fundament ukraińskiej terminologii informatycznej, 2) hegemonii języka rosyjskiego zarówno w obrębie dostępnego na rynku ukraińskim oprogramowania, jak i literatury fachowej, 3) wpływie języka rosyjskiego na ukraińskie zasoby językowe, w tym również w obrębie terminologii informatycznej, 4) niewystarczającym zaangażowaniu się ukraińskich lingwistów w kwestie tworzenia terminologii informatycznej oraz niedostatecznej ilości prac poświęconych temu zagadnieniu, 5) hermetyzacji środowiska posługującego się tym rodzajem słownictwa itd.

Istotnym i jednym z podstawowych elementów współtworzących słownictwo informatyczne są nazwy podzespołów komputerowych, które pojawiają się w niemal każdym opracowaniu dotyczącym zagadnień informatycznych. Nominacje takie jak прочесор, принтер, монітор, сzу клавіатура шуstępować będą zarówno w publikacjach poświęconych internetowi, projektowaniu stron www, programom graficznym, jak i w „bibliach” obsługi systemów operacyjnych czy programów biurowych.

W niniejszym artykule omówione zostanie pochodzenie, budowa i funkcjonowanie większości ukraińskich nazw części, podzespołów komputerowych i wybranych akcesoriów spotykanych w literaturze informatycznej, ale i na stronach internetowych sklepów komputerowych, które z racji stałego kontaktu z nowościami ze świata IT są nieocenionym źródłem słownictwa, tak fachowego, jak i nieformalnego, spotykanego choćby w komentarzach klientów, którzy nabyli daną część czy podzespół.

Źródeł ukraińskiego słownictwa informatycznego poszukiwać należy w zasadzie w obrębie trzech systemów językowych. Bazą bezsprzecznie jest tu język ukraiński. Jednak udzielenie odpowiedzi na pytanie, w jakim procencie stanowi on swoisty fundament terminologiczny, wziąwszy pod uwagę dynamikę rozwoju tego podsystemu

${ }^{1}$ Historia informatyki na Ukrainie sięga końca lat 50. minionego wieku. To tutaj powstawały pierwsze komputery, jak również maszyny kierowane do produkcji seryjnej i wykorzystywane później w wielu krajach zrzeszonych w ramach RWPG. Prace nad pierwszym szerzej wykorzystywanym komputerem „Kijów” rozpoczęte pod kierownictwem Siergieja Lebiediewa ukończono przy współudziale Wiktora Hłuszkowa. Komputer ten wykorzystywano do obliczeń w Centrum Obliczeniowym AN USRR, a także w Instytucie Badań Jądrowych w Dubnie. Kolejną ważną konstrukcją stanowiącą istotny krok w rozwoju radzieckiej cybernetyki był komputer "Dniepr” stworzony w niecałe 3 lata przez W. Hłuszkowa i Borysa Malinowskiego. Maszyna była pierwszym seryjnie produkowanym komputerem na bazie tranzystorów. Wykorzystywano ją m.in. w Centrum Lotów Kosmicznych podczas misji Sojuz-Apollo. Następnym projektem opracowanym w Instytucie Cybernetyki był „Promień” — pomyślany jako maszyna do m.in. obliczeń inżynieryjnych. Jego następcami były maszyny „Mir-1” (zakupiony przez amerykański koncern IBM na targach w Londynie w 1967 r.), „Mir-2” i „Mir-3” niemające wówczas konkurencji pod względem mocy obliczeniowej. Komputery serii „Mir” wykorzystywano na terytorium całego ZSRR. Prace nad maszynami liczącymi kontynuowano z powodzeniem w latach 70-tych w wielu ośrodkach naukowo-produkcyjnych USRR. Powstawały modele produkowane w krótkich seriach, jak choćby najpotężniejsze u progu lat 80-tych ES-2701 i ES-1766, czy wykorzystywane w wielu gałęziach przemysłu jednostki typu „Newa” (dla systemów telefonicznych), „Skorpion” (kierowanie rakiet), „Iskra” (rodzina maszyn klawiszowych), systemy kierowania typu „SO-01” - „SO-04”, cała rodzina systemów pokładowych „MIG-1”, „MIG-11”, „MIG-13”, komputerów pokładowych „Ekspress”, „Etalon” i ich następców, wśród których wspomnieć należy jednostkę „Delta” wykorzystywaną w obróbce danych zebranych podczas przelotu komety Halleya. Ogółem począwszy od lat 60 . w laboratoriach, instytutach i zakładach USRR powstało ponad 30 oryginalnych typów komputerów wykorzystywanych w różnych dziedzinach nauki i przemysłu. Prace nad systemami komputerowymi kontynuowane są dziś w Instytucie Cybernetyki NAN Ukrainy im. Hłuszkowa.

Pomimo, że gros prac stanowiących o sile radzieckiej myśli informatycznej odbywało się na Ukrainie, trudno przypuszczać, by język ukraiński odgrywał w tym procesie istotniejszą rolę. Wskazywać na to mogą chociażby prace wybitnych uczonych biorących udział w wielu z opisanych projektów, rzecz jasna w języku rosyjskim, np. В. М. Глушков, Синтез циифровых автоматов, Москва 1962; В. М. Глушков, Введение в кибернетику, Киев 1964; В. М. Глушков, Основы безбумажной інформатики, Москва 1987 i in. 
języka, może być dość problematyczne. Język ukraiński stanowi tu swego rodzaju matrycę, w którą jak elementy układanki wpasowują się elementy obce.

Czynnikami obcymi mającymi ciagły wpływ na wzbogacanie, czy jak twierdzi wielu badaczy zaśmiecanie zasobów leksykalnych języka ukraińskiego, w tym również terminologii informatycznej, są głównie język angielski oraz w nieco mniejszym stopniu język rosyjski. To zróżnicowanie uzależnione jest od czasu, polityki i koniunktury na rynku.

Niewątpliwym truizmem będzie stwierdzenie, iż faktyczny rozwój ukraińskiego słownictwa informatycznego przybrał na sile w ostatnich latach XX w., ale przede wszystkim w pierwszej dekadzie obecnego stulecia. Początki ukraińskiej myśli informatycznej, a więc lata 60-te, 70-te, wiązać należy w głównej mierze z językiem rosyjskim, zaś obecność w owym czasie języka ukraińskiego traktować wypada chyba jedynie w kategoriach wyjątku. Na potwierdzenie tych słów warto przytoczyć słowa prof. Myrosława Kratki, współpracownika prof. Wiktora Hłuszkowa przy projekcie Енциклопедія кібернетики, pierwszego tego rodzaju kompendium na świecie: „Однак і ті автори, які жили в Україні та знали українську мову, писали російською, посилаючись на те, що вони не знають української термінології. Важку роботу перевести все на українську мову взяла на себе редакція літературного контролю УРЕ. Пишу „перевести”, а не „перекласти”, бо це справді була робота не тільки перекладацька, а й термінологічна, адже українських кібернетичних термінів ще не було. В УРЕ було правило: якщо видання готується двома мовами, матеріал не приймуть до того часу, доки обидва варіанти український і російський - не будуть готові. Отже, коли на початок 1973 року треба було здавати енциклопедію в друк, виникло питання, який варіант вийде у світ першим. Микола Бажан хотів, щоб україномовна енциклопедія була першою, а Віктор Глушков - щоб першим був російський варіант"2.

Ostatecznie jako pierwszy światło dzienne ujrzał wariant ukraiński, jednak było to jedno z niewielu wydawnictw w tym języku i, biorąc pod uwagę ogromną dynamikę rozwoju tej dziedziny nauki, a co za tym idzie olbrzymią płynność w obrębie terminologii, należy stwierdzić, iz nie odegrało większej roli w konstytuowaniu się ukraińskiej terminologii informatycznej.

Tak naprawdę zaczęła ona funkcjonować dopiero pod koniec minionego wieku. Nie należy zapominać, że wszelkie nowinki technologiczne, import sprzętu, oprogramowania, publikacji książkowych z zakresu informatyki odbywał się przy udziale przedsiębiorstw i instytucji rosyjskich. Tę samą drogę pokonywało słownictwo informatyczne, a zalew ukraińskiej przestrzeni językowej terminami z zakresu informatyki i nowoczesnych technologii przybrał na sile wraz z rozwojem sieci internetowej.

Rzecz jasna tak silne związki języka ukraińskiego z językiem rosyjskim ze szczególnym uwzględnieniem kwestii wzajemnych zapożyczeń to nie tylko okres ostatniego stulecia. Relacje te sięgają o wiele głębiej, bo połowy wieku XVII. Stały się one od tego czasu bardziej lub mniej regularne, charakteryzując się zróżnicowaniem nasilenia obustronnych wpływów, różnorodnością sfer socjalnych czy stylistycznych, do których przenikały poszczególne elementy, jak również niejednakowym poziomem adaptacji zapożyczeń. $\mathrm{O}$ ile przez pierwszych kilkadziesiąt lat tych relacji ${ }^{3}$ można mówić o w zasadzie równomiernym wpływie obu języków na siebie,

${ }^{2}$ Źródło elektroniczne: http://www.istpravda.com.ua/digest/4d4fb3c09e453/, dostęp 12.10.2011 r.

${ }^{3}$ Wpływy języka ukraińskiego na język rosyjski w tym okresie nie ograniczały się jedynie do sfery tradycyjnych kontaktów międzyludzkich (w języku rosyjskim pojawiły sie wówczas m.in.: смак, смачный, шинок, шинкарь, злочинеи, шукать, повинности) czy pośredniczeniu w przyswajaniu zapożyczeń (poprzez język ukraiński do języka rosyjskiego trafiły m. in. z języka polskiego leksemy 
o tyle lata późniejsze począwszy od reform Piotra I to już głównie dominacja języka rosyjskiego i usuwanie języka ukraińskiego z wielu sfer życia społecznego.

Wpływ języka rosyjskiego na język ukraiński przejawiał się w zapożyczeniach bezpośrednich przy ukraińskiej adaptacji fonetycznej czy słowotwórczej (np. більшовик, вертоліт), kalkowaniu (піонер, радянський, супутник, n'ятирічка), rzadziej bez takiej adaptacji (тройка, льотчик, духовка, політрук). Oddziaływanie to nie ograniczało się jedynie do leksyki, gdyż w obrębie ukraińskich modeli słowotwórczych czy form gramatycznych pojawiać zaczęły się struktury dotychczas nie wykorzystywane.

Prócz przenikającego z języka rosyjskiego do języka ukraińskiego słownictwa czy pewnych modeli gramatycznych, które można usprawiedliwić choćby wspólnymi korzeniami obu języków, odnotować należy ogromną ilość struktur, które przy wsparciu zrusyfikowanej wymowy przekształcają język ukraiński w twór „,rosyjskopodobny", nр.: ладно, больниия, часи, дома́; я рахую, щэо.., дякую вас, згідно списку, лекція по хімії i in.

Czy zatem proces powstawania ukraińskiej terminologii informatycznej to 1) niezależne ukuwanie terminologii ukraińskiej z szerokimi wpływami języka rosyjskiego czy też 2) wyłanianie się z rosyjskich zasobów terminologicznych elementów ukraińskich? Wydaje się, iż odpowiedź na to pytanie nie może być jednoznaczna. Biorąc zatem pod uwagę fakt wszechstronnych wpływów języka rosyjskiego w okresie narodzin ukraińskiego słownictwa informatycznego, ostatnią dekadę XX w. należy uznać za czas chaotycznej rywalizacji w obrębie omawianego słownictwa pomiędzy językiem ukraińskim a rosyjskim, zaś minione dziesięciolecie określić mianem ,galopującej anglicyzacji "'. Wiele terminów zapożyczonych w tamtym okresie $\mathrm{z}$ języka rosyjskiego $\mathrm{w}$ dzisiejszych realiach już nie funkcjonuje, ustępując miejsca nowym i zupełnie wychodząc z użytku.

Problemowi obecności języka rosyjskiego w obrębie słownictwa informatycznego, czystości języka ukraińskiego szczególnie wiele miejsca poświęcają naukowcy lwowscy ${ }^{5}$. W publikacjach poświęconych kwestiom językowej lokalizacji komputera zwracają uwagę nie tylko na problemy stricte językowe, ale również egzystencjalne związane z wychowywaniem kolejnego pokolenia młodych Ukraińców; wychowaniem w cyfrowym świecie, w którym porozumiewać się będą w języku ukraińskim, wolnym od terminologii rosyjskiej czy swoistego trójjęzycznego surżyka. Bohdan Rycar, Roman Mysak i Roman Mykulczyk stwierdzając, że język rosyjski wciąż pozostaje głównym źródłem zapożyczeń i kalk językowych w obrębie słownictwa informatycznego wskazują na liczne nieprawidłowości wynikające na tym polu, m.in.: a) używanie imiesłowów przymiotnikowych czynnych z sufiksem -аюч-, -уюч- (апроксимуючий, впливаючий, друкуючий, запам'ятовуючий, швидкодіючий i in.), b) kalki z języka rosyjskiego, m.in. видаляти, друкувальний, загружсати, квадратні скобки, круглі скобки, рознім, скачувати, словарна стаття, c) liczne błędy ortograficzne i niezgodności gramatyczne, np.: 365 доби, відео в реальному часу, три головних сервіси, d) nagminne używanie rzeczowni-

кафедра сzу метрика). Do rosyjskiej sfery liturgicznej przeniknęła choćby ukraińska wymowa spółgłoski $\Gamma$ w wariancie frykatywnym, nie zaś zwarto-wybuchowym (Господь, Бог, благо, глас).

${ }^{4}$ Osobną kwestią pozostaje tu droga zapożyczenia. Wiele terminów anglojęzycznych funkcjonujących dziś w ramach ukraińskiej terminologii informatycznej weszło w jej skład przy pośrednim udziale języka rosyjskiego.

${ }^{5}$ Б. Рицар, Р. Мисак, Р. Микульчик, Про англійсько-украӥнський глосарій виробів Місrоsoft, [в:] Проблеми української термінологї, 2006, с. 28-30. 
ków odczasownikowych nazywających czynności ${ }^{6}$ na -к (a) typu вкладка, закладка, заливка, настройка, перевірка, правка, розкладка, розсилка іtр.

Piętnując błędy proponuja jednocześnie prawidłowe warianty poszczególnych leksemów. W artykule z 2003 roku $^{7}$ przedstawili całe gniazdo składające się z niewłaściwych dla języka ukraińskiego czasowników i rzeczowników odczasownikowych $\mathrm{z}$ rdzeniem ключ podając rozwiązania mieszczące się $\mathrm{w}$ granicach norm języka ukraińskiego, nр.: переключення, переключати (режими, відображення, між документами тощо) $\rightarrow$ перемикати, перемикання; перемкнути, перемкнення, albo: підключання, підключати; підключення, підключити $\rightarrow$ (до мережі, пристрою) підлучати, підлучання; підлучити, підлучення; під'єднувати, під'єднування; під'єднати, під'єднання i in.

Zagadnienia poprawności językowej oraz problemy zapożyczeń z języka rosyjskiego nie są przedmiotem zmartwień jedynie naukowców. Obecność języka rosyjskiego w obrębie słownictwa komputerowego, zapożyczeń z tego języka jest jak się okazuje na tyle uciążliwa, że wywołuje reakcje wśród wielu użytkowników, którym nie jest obojętne to w jakim języku prowadzą dialog ze swym komputerem. Wystarczy przytoczyć jedynie dwa $\mathrm{z}$ wielu wpisów na forach internetowych, by przekonać się o wadze zjawiska: „Я особисто бачу проблему в тому, що всі іншомовні запозичення приходять в українську мову тільки і виключно з мови російської. Тобто, якщо в Москві вирішують щось перекласти скажімо з англійської, то „спеціалісти” приймають українським стандартом або сам російський термін (татарсько-російський ярльк замість англійського shortcut — яскравий приклад ідіотизму цієї ситуації) або перекладають... але не оригінальний термін, а російський. Я розумію, що чекати поки „спеціалісти” по філіалізації української мови, вивчать ще якусь мову крім російської це справа довга. Може між тим все ж вживати терміни з мови оригіналу, а не тільки з російської. Користувач Олесь абсолютно згідний. Для мене такі слова - однозначно русизми, оскільки прийшли в українську через російську, навіть якщо первинно це слово походить з якої завгодно іншої мови"8.

„До публікацій О. Кочерги та Н. Непийводи „Висловлювальні можливості української мови та втілення їх у термінотворенні": У публікації йде мова про запозичування іншомовних конструкцій, що сприяє поширенню російського канцеляриту у термінології, неточності перекладу з англомовних джерел, про негативну роль мови-посередника, якої переважно є російська, бо через неї ми нерідко отримуємо спотворені терміни типу хакер, замість гекер тощо" .

Aktywność użytkowników nie ogranicza się jedynie do komentarzy. Na wielu stronach internetowych ${ }^{10}$ można odnaleźć propozycje zmian, które dotyczą terminów zapożyczonych, przede wszystkim z języka rosyjskiego, rzadziej angielskiego bądź też zmiany terminów nie do końca, według autorów, „trafionych” np.: браузер $\rightarrow$

${ }^{6} \mathrm{Co}$, jak piszą badacze, znajduje się w opozycji do wymogów zawartych w dokumencie Держстандарту України ДСТУ 3966-2000 Термінологія. Засади і правила розробляння стандартів на терміни та визначення понять.

${ }^{7}$ Б. Рицар, Р. Мисак, Мова та термінологія зукраӥнізованих програмних продуктів фірми Майкрософт, [в:] “Вісник Національного університету «Львівська політехніка»”, 2003, № 490, c. $17-24$.

${ }^{8}$ Źródło elektroniczne: http://misto.ridne.net/thread-2385.html; dostęp 12.09.2011 r.

${ }_{9}^{9}$ Źródło elektroniczne:http://www.refine.org.ua/pageid-3248-2.html; dostęp 12.09.2011 r.

10 Źródło elektroniczne:http://novamova.wikia.com/wiki/\%D0\%9F\%D0\%B8\%D1\%82\%D0\%BE $\%$ D 0\%BC\%D0\%B0_\%D0\%BA\%D0\%BE\%D0\%BC\%D0\%BF\%27\%D $1 \% 8$ B $\%$ D $1 \% 82 \%$ D0\%B5\%D1\%80\%D0\%BD $\%$ D0\%B0 \%D1\%82\%D0\%B5\%D1\%80\%D0\% BC $\%$ D $1 \% 96 \%$ D0 $\%$ BD $\%$ BC $\%$ D $1 \% 96 \%$ D0\%BD $\%$ D0\%BE\%D0\%BB\%D0\%BE\%D0\%B3\%D1\%96\%D1\%8F ; dostęp 19.07.2011 r. 
переглядач, проглядач; видалити $\rightarrow$ вилучити, виноска $\rightarrow$ виносити, винести; відмінити $\rightarrow$ скасувати, відкликати, відмовити; довідка $\rightarrow$ поміч, допомога; імпорт $\rightarrow$ вичит, ім'я (файлу) $\rightarrow$ назва, качати $\rightarrow$ завантажувати, стягувати, ладувати; колонки $\rightarrow$ стовпчики, експортувати $\rightarrow$ винести, маркер $\rightarrow$ позна(ч) $\kappa a$, настройка $\rightarrow$ настроювати, настроювання, ладнати, ладнання; область $\rightarrow$ ділянка, поле; панель $\rightarrow$ дошка, панель інструментів $\rightarrow$ панель засобів, папка $\rightarrow$ тека, каталог; правка $\rightarrow$ виправляти, виправляння; пробіл $\rightarrow$ прогалина, пропуск; трафік $\rightarrow$ перебіг $\mathrm{i}$ in.

Zapożyczenia z języka rosyjskiego czy wręcz rosyjskie „wstawki” obecne w zukrainizowanych interfejsach wielu programów komputerowych, systemów operacyjnych, publikacjach o tematyce informatycznej, na stronach internetowych niewątpliwie stanowią problem i wywierają niekorzystny wpływ na konstytuowanie się rodzimej leksyki komputerowej.

Aby uporządkować tok prowadzonego tu wywodu, należy rozpocząć od prezentacji nazw części i podzespołów komputerowych, które nie zawierają żadnych elementów obcych, bądź też od lat funkcjonują na gruncie języka ukraińskiego.

Wśród nazw rodzimych wymienić należy zatem leksemy takie jak: гучномовець, колонка 'głośnik', з'єднувач 'wtyczka', зчитувач 'czytnik', килимок 'podkładka pod mysz', карман/кишеня 'kieszeń', миша 'mysz', кермо 'kierownica', навушники 'słuchawki', накопичувач 'dysk', охолоджувач 'wentylator', перехідник 'kontroler', подовжувач 'przedłużacz', програвач 'tuner, odtwarzacz', розгалужсвач 'hub', чорнило 'atrament'. Dla części z przytoczonych tu nazw, jak choćby dla nominacji килимок, кишеня, миша сzу чорнило ich znaczenie informatyczne jest sekundarne, zaś samo przeniesienie znaczenia nastapiło np. na skutek podobieństwa zewnętrznego czy wykonywanej funkcji.

Obecność zapożyczeń leksykalnych w zasobach języka ukraińskiego, a w szczególności terminologii informatycznej jest znacząca. Większość z nich pochodzi z języka angielskiego, nieliczne z innych języków (np. z niem. кабель 'kabel', шлейф 'taśma'). Fakt ten potwierdza wielu językoznawców m.in. Ołeksandr Styszow, który zauważa, że zapożyczenia z języka angielskiego stanowią dziś ok. 70-80\% wszystkich nowości leksykalnych w języku ukraińskim ${ }^{11}$. Pod tą tezą podpisuje się choćby Hałyna Szapowałowa stwierdzając, iż zapożyczenia z dziedziny informatyki należą do grona najczęstszych we współczesnym języku ukraińskim ${ }^{12}$.

Należy w tym miejscu jednak zauważyć, iż szlak wielu terminów wywodzących się z języka angielskiego a zaadoptowanych na gruncie ukraińskim wiedzie przez język rosyjski, mowa tu zatem o złożonym kontakcie zapożyczenia. Do leksemów zapożyczonych z języka angielskiego pośrednio lub bezpośrednio należą m.in.: aдаптер 'adapter', бокс 'opakowanie na płyty CD/DVD', вентилятор 'wentylator', вінчестер 'dysk twardy', геймпад 'pad', джойстик 'joystick', динамік 'głośnik', картридж 'kartridż', картрідер 13 'czytnik kart pamięci', конектор 'wtyczka', контролер 'kontroler', кониентратор/хаб 'hub', марирутизатор/роутер 'router', мікрофон 'mikrofon', модем 'modem', монітор/дисплей 'monitor', ноутбук/лептоп 'notebook/laptop', презентер 'wskaźnik laserowy', принтер 'drukarka', процесор 'procesor', сабвуфер 'subwoofer', сервер 'serwer', ска-

${ }^{11}$ О. Стишов, Особливості розвитку лексичного складу украйнської мови кінця ХХ ст., [в:] “Мовознавство”, Київ 1999, № 1, с. 7-21.

${ }^{12}$ Г. Шапов алова, Джерела сучасної неологічної лексики іншомовного походження та доциільність ї̈ використання, [в:] “Вісник Львівського університету”, сер. Журналістика, Львів 2003, № 23 , c. $120-124$.

${ }^{13}$ Spotykane również warianty кард-pidep, карm-рiдер. 
нер 'skaner', сплітер 14 'rozgałęźnik', тонер 'toner', трекбол 'trackball', тюнер 'tuner', yin 'chip'.

Równie często jak przytoczone leksemy, w ramach słownictwa komputerowego spotykane są nazwy podzespołów, które powstały w rezultacie odwzorowania struktury jednostki leksykalnej właściwej dla innego języka, czyli kalki. Z uwagi na to, że są to struktury o większym stopniu złożoności, liczba ukraińskich wariantów poszczególnych podzespołów, wariantów tłumaczeniowych jest także o wiele wyższa, np.: аудіоплата, звукова карта, звукова плата 'karta dźwiękowa' $<$ ang. sound card, audio card; багатофункціональний пристрій 'urządzenie wielofunkcyjne' < ang. Multi Function Product (MFP); блок безперебійного жсивлення, пристрій безперебійного живлення, пристрій захисту від аварійних перепадів напруги 'zasilacz UPS' < ang. Uninterruptible Power Supply (UPS); блок водяного охолодження, водяне охолодження, водяний блок 'blok wodny' < ang. water block; блок живлення 'zasilacz' < ang. Power Supply Unit (PSU); веб-камера' 'kamerka internetowa' < ang. webcam; відеокарта, графічна карта, графічний адаптер, графічний прискорювач 'karta graficzna' < ang. video card, graphics card, video adapter, display adapter, graphics accelerator card; головна плата, системна плата, материнська плата 'płyta główna' < ang. mainboard, motherboard; докстаниія 'stacja dokująca' < ang. docking station; жорсткий диск 'dysk twardy' < ang. Hard Disk Drive (HDD); замок для ноутбука, замок безпеки для ноутбука, трос-замок для ноутбука, тросик до ноутбука 'zamek do notebooka' < ang. notebook lock; зарядний пристрій/адаптер для ноутбука 'ładowarka/adapter do notebooka' < ang. laptop adapter charger; зчитувач карток флеш-пам'яті, зчитувач флеш-карт, зчитувач смарт-карток 'сzytnik kart pamięci' < ang. memory card reader; інтерактивна дошка, інтерактивна дошка прямої проекиії 'tablica interaktywna' < ang. interactive whiteboard; Інтернет карточка, Інтернет-картка, картка поповнення Інтернет, картка доступу до мережі Iнтернет 'karta internetowa' < ang. internet card; комп 'ютерна клавіатура 'klawiatura komputerowa' < ang. computer keyboard; концентратор USB 'hub USB' < ang. USB hub; мережева карта 'karta sieciowa' < ang. network interface card; оперативна пам'ять, оперативний запам'ятовуючий пристрій, модуль пам 'яті 'pamięć RAM' < ang. random-access memory; привід оптичний, привід оптичних дисків, оптичний привід $D V D / C D$ 'napęd optyczny' < ang. Optical Disc Drive (ODD); підставка для ноутбука, підставка під ноутбук, підставка-охолоджувач під ноутбук, охолоджуюча підставка для ноутбука 'podstawka chłodząca' < ang. cooling pad; nривід магнітних дисків, привід FDD 'napęd FDD' < ang. Floppy Disk Drive (FDD); сумка для ноутбука, рюкзак до ноутбука, кейс для ноутбука 'torba do notebooka' $<$ ang. notebook case; TB програвач ${ }^{16}$ 'tuner TV' < ang. TV-Tuner; mермопаста 'pasta termoprzewodząca' < ang. thermal paste; флеш-пам 'ять, пристрій пам'яті USB, USB флеш накопичувач, USB-накопичувач 'pamięć flash' < ang. flash memory, USB flash drive, flash disk; центтральний процесор 'główny procesor' < ang. Central processor unit (CPU) $\mathrm{i}$ in.

Z punktu widzenia budowy poszczególnych nominacji przytoczone przykłady nazw ukraińskich części i podzespołów komputerowych należałoby zgrupować w dwóch zbiorach. Nieznacznie przeważają tu nazwy składające się z jednego członu, a są to zarówno leksemy rodzime, jak i zapożyczenia, np.: адаптер, бокс, вентилятор, вінчестер, геймпад, гучномовець, джойстик, динамік, дисплей, з'єднувач,

\footnotetext{
14 Także cnлimmep.

15 Także web-камера, вебкамера.

${ }^{16}$ Także warianty mюнер TВ/ФМ, ТВ/ФМ-тюнер, ТВ-тюнер, TВ тюнер, TV/FМ тюнер.
} 
зчитувач, кабель, карман, картридж, картрідер, кермо, килимок, кишеня, клавіша, кнопка, колесо, колонка, конектор, контролер, концентратор, корпус, лептоп, маршрутизатор, миша, мікрофон, модем, монітор, навушники, накопичувач, нетбук, ноутбук, охолоджувач, перехідник, подовжувач, презентер, принтер, програвач, прочесор, розгалужувач, роутер, сабвуфер, сервер, сканер, слот, сплітер, тонер, трекбол, тюнер, хаб, чіп, чорнило i in.

Równie liczną grupę stanowią struktury bardziej złożone. Wśród grup wyrazowych składających się z dwóch komponentów, w których członem konstytutywnym jest określany rzeczownik obecne są skupienia atrybutywne, np.: багатофункціональний пристрій, водяне охолодження, водяний блок, головна плата, графічна карта, графічний адаптер, графічний прискорювач, жорсткий диск, звукова карта, звукова плата, інтерактивна дошка, комп 'ютерна клавіатура, материнська плата, мережева карта, оперативна пам'ять, привід оптичний, системна плата, центральний процесор i in. oraz skupienia genetywne, w których członem akcesorycznym jest rzeczownik w dopełniaczu. Są to głównie konstrukcje z przyimkiem, np.: адаптер для ноутбука, блок живлення, замок для ноутбука, кейс для ноутбука, модуль пам'яті, підставка для ноутбука, підставка під ноутбук, рюкзак до ноутбука, сумка для ноутбука, тросик до ноутбука i in. Ukraińskie nazwy podzespołów komputerowych to także skupienia złożone, składające się z więcej niż dwóch komponentów. W wielu wypadkach są to zmodyfikowane skupienia proste, w których pojawił się dodatkowy element podrzędny, np.: блок безперебійного живлення, блок водяного охолодження, зчитувач карток флешпам'яті, інтерактивна дошка прямої проекиї, картка доступу до мережі Інтернет, картка поповнення Інтернет, оперативний запам'ятовуючий пристрій, охолоджуюча підставка для ноутбука, привід магнітних дисків, привід оптичних дисків, пристрій безперебійного живлення, пристрій захисту від аварійних перепадів напруги, пристрій пам'яті USB i in.

Przytoczone tu przykłady nazw podzespołów i części komputerowych w postaci skupień złożonych, połączeń dwuwyrazowych oraz nazw jednowyrazowych funkcjonują w ramach struktur, w których stanowią one rdzeń kolejnych związków wyrazowych. Z oczywistych względów najłatwiej w tego typu konstrukcjach odnajdują się nazwy podzespołów składające się z jednego członu. Skupienia (tak proste, jak i złożone), w których elementem nadrzędnym są wymienione wcześniej nazwy, z reguły konkretyzują parametry, budowę, wygląd zewnętrzny czy przeznaczenie opisywanego podzespołu.

Poniżej tabela, której lewa kolumna zawiera człony konstytutywne danych związków wyrazowych, w prawej kolumnie zaś umieszczono niektóre elementy określające poszczególne rzeczowniki i związki wyrazowe.

\begin{tabular}{|l|l|}
\hline $\begin{array}{l}\text { багатофункиіональний } \\
\text { прстрій }\end{array}$ & лазерний, струменевий \\
\hline веб-камера & $\begin{array}{l}1.3 \text { мегапіксельна, бездротова, вбудована, зовнішня, } \\
\text { мережева, персональна, стандартна }\end{array}$ \\
\hline \multirow{3}{*}{ вентилятор } & $\begin{array}{l}\text { дл відеокарт, для жорстких дисків, для корпусів, } \\
\text { дл материнських плат, для процесорів Intel, для } \\
\text { прочесорів універсальний, для чіпсета материнсь- } \\
\text { ких плат, для чіпсетів, до корпусу), до ноутбука, } \\
\text { до північного моста материнської плати, корпус- } \\
\text { ний, прочесорний }\end{array}$ \\
\hline
\end{tabular}




\begin{tabular}{|c|c|}
\hline вінчестер & $\begin{array}{l}\text { анти-иок, безшумний, білий, внутрішній, гібридний, } \\
\text { до ноутбуків, екологічний, зовнішній, мобільний, } \\
\text { прохолодний, срібний, титан, червоний, чорний }\end{array}$ \\
\hline динамік & $\begin{array}{l}\text { вертикальний, високопотужний, двухполосний, } \\
\text { коаксіальний, портативний }\end{array}$ \\
\hline звукова плата & $\begin{array}{l}\text { аналогова, віртуальна, зовнішня, інтегрована, } \\
\text { окрема, професійна, розширення у роз'єм шини РСI }\end{array}$ \\
\hline кабель & $\begin{array}{l}\text { 4-х жсльний, активний кабель з чипсетом, висо- } \\
\text { кочвидкісний, для зовнішньої прокладки КПП-ВП, } \\
\text { для ноутбуків, для підключення USB пристроїв, для } \\
\text { підключення портативних цчифрових пристроїв, } \\
\text { екранований, живлення, з позолоченим итекером, } \\
\text { з позолоченими конекторами, з феритовими кіль- } \\
\text { иями, з'єднувальний, комутаційний, прозорий сріб- } \\
\text { ний, сигнальний }\end{array}$ \\
\hline клавіатура & $\begin{array}{l}\text { Blиетооть-, WiFi-, ультра-тонка, безпровідна, водо- } \\
\text { непроникна, гнучка, д/геймерів, дротова, еластич- } \\
\text { на, з іонізатором повітря, з підсвітленням кла- } \\
\text { віш, з регулятором звуку, з роз'ємом під навушники } \\
i \text { мікрофон, ігрова, коротка, мультимедійна, } \\
\text { оптична, портативна зовнішня, резинова гнучк, } \\
\text { стандартна, числова }\end{array}$ \\
\hline корпус & $\begin{array}{l}\text { з вентилятором на задній стіниі, з дверкою, чор- } \\
\text { ний, чорно-синій, чорно-срібний, чорно-червоний }\end{array}$ \\
\hline мишка & $\begin{array}{l}\text { USB-, бежсева з візерунком, бездротова, безпровід- } \\
\text { на, біла глянцева, в червоні клітинки, вболівальни- } \\
\text { чя, дротова, ігрова, інфрачервона, лазерна, меха- } \\
\text { нічна, міні, молочно-золотава, надшвидкісна, на- } \\
\text { півпрозора, оптична, радіо-оптична, рожева, } \\
\text { рожево-золотава, синьо-чорна, сіро-помаранчова, } \\
\text { сіро-чорна, срібляста, сріблясто-чорна, стандарт, } \\
\text { темно-сіра, у вигляді машинки, у вигляді сери,, } \\
\text { у вигляді футбольного м'яча, червона з сердечком, } \\
\text { чорна, чорно-золотава, чорно-червона }\end{array}$ \\
\hline мікрофон & $\begin{array}{l}\text { „гусяча шия”, для ноутбука, на підставщі у вигляді } \\
\text { ручки, настільний з підставкою }\end{array}$ \\
\hline монітор & $\begin{array}{l}\text { глянцовий, електронно-променевий, плазмовий, } \\
\text { проекційний, рідкокристалічний, стандартний, } \\
\text { чорний гляни, чорний суперглянц, чорний, широко- } \\
\text { форматний }\end{array}$ \\
\hline навуиники & $\begin{array}{l}\text { безпровідні, -вкладиші, голубий металік, з позоло- } \\
\text { ченим роз'ємом, з проводом, з регулятором звуку, } \\
\text { з регулятором рівня гучності, затилочні, -кліпси, } \\
\text { накладні, оранжеві, срібні, чорні }\end{array}$ \\
\hline
\end{tabular}




\begin{tabular}{|c|c|}
\hline принтер & $\begin{array}{l}\text { кольоровий, лазерний, матричний, монохромний, } \\
\text { портативний, струменевий, чорно-білий }\end{array}$ \\
\hline проектор & $\begin{array}{l}\text { електронний, з роз'ємом DVI-I, з технологією } \\
\text { 3LCD, інтерактивний, мультимедійний, офрісний, } \\
\text { портативний, самодостатній, цчифровий }\end{array}$ \\
\hline прочесор & $\begin{array}{l}\text { 32-бітовий, 32-нанометровий, багатоядерний, } \\
\text { восьмиядерний, двоядерний, десктопний, } з \text { архі- } \\
\text { тектурою ІАЗ2, командний, мобільний, настільний, } \\
\text { n'ятого покоління, сімейства Intel Соге, чотирьо- } \\
\text { ядерний, шестиядерний }\end{array}$ \\
\hline радіатор & $\begin{array}{l}\text { алюмінієвий, для відео пам'яті, длямодулів пам'яті, } \\
\text { з алюмінію, з вентилятором, з міді, зовнішній, про- } \\
\text { цесора, мідний, на пам'ять, повітряного охоло- } \\
\text { дження прочесора, процесора, системи охоло- } \\
\text { дження процесора }\end{array}$ \\
\hline сканер & $\begin{array}{l}\text { аркушопротяжний, барабанний, книжковий, лис- } \\
\text { товий, мобільний, настільний, планетарний, план- } \\
\text { метний, портативний, ручний }\end{array}$ \\
\hline тюнер & $\begin{array}{l}\text { аналоговий, без пульту ДК, внутрішній, з д/к, зов- } \\
\text { нішній USB2.0, зовнішній незалежннй, супутник- } \\
\text { вий, універсальний зовнішній, цичфровий }\end{array}$ \\
\hline илейф & $\begin{array}{l}\text { 39-піновий, 4-канальний, 80-жильний плоский, СОМ } \\
\text { порту, від блока живлення, для НDD, для СНПЧ, } \\
\text { інтерфейсний, інформаційний, комп 'ютерний, } \\
\text { міжсплатний, передачі даних, плати управління та } \\
\text { індикацїі, стандартний, широкий }\end{array}$ \\
\hline шнур & $\begin{array}{l}\text { mini USB2.0, до принтера, до ичифрових камер, } \\
\text { живлення комп'ютер-монітор, живлення, обмід- } \\
\text { нений, універсальний }\end{array}$ \\
\hline
\end{tabular}

Omawiane leksemy zajmują w związkach wyrazowych również pozycję podrzędną. Występując w funkcji elementu precyzującego znaczenie konkretnego skupienia wskazują jednocześnie na część czy podzespół komputerowy, którego dany związek wyrazowy dotyczy. Oto jedynie niektóre z wyekscerpowanych przykładów: архітектура процесора, високошвидкісна пам'ять процесора, внутрішня пам'ять процесора, драйвер сканера, живлення гнізд пам'яті, контролер сканера, кристал процесора, кріплення радіатора, лінійка процесорів Intel Core другого покоління, менеджмент кабелів, мікросхеми приховані під радіатором, модель сканера, можливість підключення веб-камери, можливості сканера, напруга процесора, настройка сканера, під'єднання сканера, підключення сканера, продуктивність сканера, пропускна здатність пам'яті, регулятор довжини кабеля, роздільність дисплею, роз'єми д/наушників і мікрофона, роз'єми для підключення графічної плати, роз'єми для підключення жсорстких дисків, роз'єми для підключення звукової плати, роз'єми для підключення оперативної пам'яті, розмір екрану, рознім для flорру-дисковода, 
розніми для підключення вентиляторів, розніми для підключення жсивлення, розрядність внутрішніх регістрів 64-бітових процесорів, стабільність процесора, стереонавушники з інтегрованим у кабель мікрофоном, стереонавушники із регульованим мікрофоном, тактова частота процесора, тепловиділення процесора, термопаста радіатора, ивидкодія процесора i in.

Celem niniejszego artykułu było przedstawienie części ukraińskiego słownictwa informatycznego; wycinka o tyle istotnego, że składają się nań nazwy podstawowych elementów, z których zbudowany jest komputer — rzecz, zjawisko, pojęcie, bez którego nie mogłaby zaistnieć fundamentalna dla naszej cywilizacji nauka, jaką jest informatyka. Wyekscerpowany z różnych źródeł faktograficznych ${ }^{17}$ materiał przeanalizowano $\mathrm{z}$ uwzględnieniem jego pochodzenia, charakterystyki formalnogramatycznej, a w szczególności liczby komponentów, z których składały się nazwy podzespołów komputerowych. Przedstawiono również wybrane związki wyrazowe, w których opisywane nominacje pełniły rolę nadrzędną i podrzędną.

Zaprezentowane przykłady wydają się świadczyć o tym, iż „kondycja” ukraińskiej terminologii informatycznej jest zupełnie niezła, a jej przyszłość niezagrożona. Niestety biorąc pod uwagę sytuację na ukraińskim rynku informatycznym, księgarskim czy wreszcie niewystarczającą ilość badaczy, którzy zechcieliby zająć się daną tematyką, należy przypuszczać, że może być zgoła inaczej. Mimo że w niektórych ukraińskich sklepach komputerowych można nabyć ukraińskojęzyczne wersje systemów operacyjnych czy oprogramowania, to wciąż jest to sytuacja wyjątkowa, bowiem w sprzedaży przeważają produkty rosyjskojęzyczne. Podobnie na rynku księgarskim - zdecydowanie dominują tu również publikacje rosyjskojęzyczne. Dostępne są wprawdzie pozycje książkowe z dziedziny informatyki w języku ukraińskim, jednak materiał, na którym bazują, czyli oprogramowanie, z reguły jest w języku rosyjskim. Wydaje się, iż jedynym w takich warunkach źródłem materiału leksykalnego pozostaje internet, strony niektórych sklepów komputerowych, fora informatyczne. Powstaje zatem kwestia tego, jak w warunkach ograniczonego dostępu do źródeł terminologii ma zostać ona sklasyfikowana, ujednolicona i w jaki sposób wpłynie to na ścieżki jej rozwoju oraz miejsce w „układance” podsystemów języka składających się na ogół zwany współczesnym ukraińskim językiem literackim.

${ }^{17}$ Англійсько-український глосарій виробів Мicrosoft ${ }^{\circledR}$ : громадська редакція, за ред. Б. Рицара, Львів 2006; Я. М. Глинський, Практикум з інформатики, Львів 2003; І. Кульчицький, М. Плеша, Технологічні аспекти вживання украӥнської мови в середовищі OC Windows II, [в:] Проблеми украӥнської термінології, 2008; В. М. Локаз юк, Ю. Г. Савченко, Надійність, контроль, діагностика і модернізація ПК, Київ 2004; О. О. Меженний, Windows XP, Москва-СанктПетербург-Київ 2004; Ж. Я. Цапо вська, Pобота з Microsoft PowerPoint 2000/2003/2007, Львів 2009; Źródło elektroniczne: http://a1market.com.ua; http://www.krez.lviv.ua/komputer.html; http:// kvest.ucoz.ua. 